\title{
DNA damage assessment among urban female street sweepers exposed to vehicular exhaust in metro Manila, Philippines
}

\author{
Annabella Villarino ${ }^{1, *}$, Glenn L. Sia Su ${ }^{2}$ \\ ${ }_{1}^{1 B i o l o g y}$ Department, College of Natural Sciences and Mathematics, Mindanao State University, Marawi, Philippines \\ ${ }^{2}$ Department of Biology, College of Art and Sciences, University of the Philippines, Manila, Philippines
}

\section{A R T I C L E IN F O}

\section{Article history:}

Received 25 February 2017

Received in revised form

21 September 2017

Accepted 1 October 2017

\section{Keywords:}

DNA damage

Comet assay

Fuel exhaust

Peripheral blood leucocytes

\begin{abstract}
A B S T R A C T
Occupational exposure to vehicular exhaust in Metro Manila, Philippines is a major human health risk concern because of the established DNA damaging potential of some of its components like Polycyclic Aromatic Hydrocarbons (PAHs). Hence, in this study, peripheral blood leucocytes of 50 urban female street sweepers and an equal number of housekeepers and housewives were analyzed for DNA damage utilizing the alkaline single cell gel electrophoresis (SCGE) or comet assay. This study also determined the influence of some demographic characteristics like age, length of fuel exhaust exposure, smoking and alcohol/coffee/tea drinking on DNA damage. Possible association of DNA damage and hematological parameters to include RBC count, WBC count, hematocrit, hemoglobin, lymphocytes and segmenters was also done. Results showed that exposure to vehicular exhaust has caused an increase in tail lengths $(8.48 \pm 3.41 \mu \mathrm{m}$ versus $19.35 \pm 8.79 \mu \mathrm{m})$ and tail moments $(1.93 \pm 1.43$ versus $8.02 \pm 5.71)$ of the leucocytes as demonstrated by the comet assay. Differences in the demographic characteristics of the study population were not significant ( $\mathrm{p}>0.05$ ) but comet assay results of the smokers, alcohol/coffee/tea drinkers with longer length of exposure to fuel exhaust recorded higher DNA damage compared to the smokers $(p<0.05)$, alcohol/coffee/tea drinkers of the reference group. Hematological parameters were not affected by fuel exhaust exposure ( $p>0.05)$. Results of the current study suggests of the possibility that constant exposure to fuel exhaust could lead to a transient increase in the levels of damage in the DNA of leucocytes and that the comet assay was a particularly sensitive technique in detecting such effects.
\end{abstract}

(C) 2017 The Authors. Published by IASE. This is an open access article under the CC BY-NC-ND license (http://creativecommons.org/licenses/by-nc-nd/4.0/).

\section{Introduction}

Rapid urbanization in the Philippines has resulted to the steady increase in the country's vehicular fleet (www.lto.gov.ph/ PlansAndPrograms. html). The United Nations Environment Programme, Richman (1994) reported combustion process of fossil fuels by the transportation sector as one of the key sources of many organic and inorganic compounds, oxidants, and acids that contribute heavily to the problem of urban air pollution. Automobile exhaust is a complex mixture of substances in either the gaseous or particle form. Notable pollutants in the exhaust include carbon monoxide (CO), hydrocarbons (HC), nitrogen oxides

\footnotetext{
* Corresponding Author.

Email Address: bellegorospe@yahoo.com (A. Villarino) https://doi.org/10.21833/ijaas.2017.012.008

2313-626X/C 2017 The Authors. Published by IASE.

This is an open access article under the CC BY-NC-ND license

(http://creativecommons.org/licenses/by-nc-nd/4.0/)
}

(NOx), volatile organic compounds (VOC's), and suspended particulate matter (Abuzo, 2005). Urban air pollutants have been associated with adverse health effects in humans ranging from chronic obstructive pulmonary diseases (COPD) and pulmonary tuberculosis among Filipino jeepney drivers (Howard and Christina, 2000), decreased lung function in Hong Kong bus drivers (Jones et al. 2006), chronic rhinitis and chronic pharyngitis in bus and taxi drivers in Shanghai (Zhou et al., 2001) and acute and chronic respiratory diseases in Japan and Europe (Kagawa, 2002). Other studies have elucidated that exposure to fuel exhaust can also lead to cardiovascular diseases (Abbey et al., 1995; Pope et al., 1995), hypertension, neurotoxicity, infertility and sterility (Krivoshto et al., 2008). A couple of human epidemiological studies showed the potential carcinogenicity of diesel exhaust and the studies of Krivoshto et al. (2008), Garshick et al. (2004), Kagawa (2002), Hansen et al. (2004), observed that long-term occupational exposures to 
diesel exhaust is associated to the increase in the relative risk of lung cancer, rectal and colon cancer (Siemiatycki et al., 1988), skin cancer (Netterstrom, 1988) and esophageal cancer (Gustavsson et al., 1993). The last decade has witnessed the increasing concern on DNA damage brought about by exposure to fuel exhaust in humans. The International Agency for Research on Cancer (IARC, 1989) has identified carcinogenic components [acetaldehyde; antimony compounds; arsenic; benzene; beryllium compounds; bis (2-ethylhexyl) phthalate; dioxins and dibenzofurans; formaldehyde; inorganic lead; mercury compounds; nickel; POM (including PAHs); and styrene] in diesel exhaust. Investigations on the association between exposure to fuel exhaust of petroleum derivate compounds and carcinogenicity risk has been conducted in various occupational groups using different genetic end-points, such as sister chromatid exchange (SCE), comet assay and micronucleus test. Increase DNA damage was also reflected by longer comet tail length due to the exposure to air pollutants in outdoor workers (30\% increase in comet tail length) of Mexico City (Tovalin et al., 2006), photocopiers working personnel (twofold increase) in India (Goud et al., 2001) and in workers in a refinery and heavy diesel vehicles traffic sites in Jeddah City (20-44 \% increase in comet formation (ElAssouli et al., 2007).

Diesel exhaust particles have been shown to generate reactive oxygen species, which in turn lead to oxidative stress and DNA damage. PAH associated with diesel exhaust are genotoxic, forming PAH-DNA adducts resulting in mutation and DNA strand breakage (Li and Nel, 2006).

In spite of the enormous body of evidences regarding the damaging effects of fuel exhaust emission investigated in other countries; apparently no study has been conducted in the Philippines addressing such concern. This study aims to provide baseline information on the DNA damage that humans incur due to continuous exposure to vehicular exhaust emissions while working in dangerous workplaces. Moreover, the use of comet assay in quantifying DNA damage among urban female workers is an initial investigation in the country and is hope to stimulate future studies in other occupationally exposed groups. The study likewise intends to qualify and quantify the DNA damage among urban female workers who are commonly exposed to fuel exhaust emissions in the workplace with the use of the comet assay.

\section{Materials and methods}

\subsection{Subjects of the study}

The population studied is composed of one hundred subjects wherein fifty (50) were female street sweepers specifically the PULIS OYSTER (Outof-School Youth Serving Towards Economic Recovery) with maximum exposure to fuel exhaust, while the other fifty (50) were minimally exposed female house helpers and housewives serving as reference group. Each subject signified in an inform consent and completed a standardized questionnaire patterned from that of the International Commission for Protection against Environmental Mutagens and Carcinogens (Carrano and Natarajan, 1988).

\subsection{Blood sampling}

A licensed medical technologist collected 3-5 ml peripheral blood samples by venipuncture into heparinised tube during the period January 2010March 2010. Collected blood samples were coded, cooled and processed within a maximum of $2 \mathrm{hr}$ period after collection. Comet assay was performed immediately after collection.

\subsection{Comet assay analysis}

The Comet assay was carried out under alkaline conditions as described by Comet Assay Trevigen kit. Lysis solution was chilled at $4^{\circ} \mathrm{C}$ for 20 min with the LMAgarose also melted for 5 minutes in boiling water and placed in a $37^{\circ} \mathrm{C}$ water bath for at least 20 minutes to allow cooling. Whole blood cells was combined at $1 \times 105 / \mathrm{ml}$ with molten LMAgarose (at $\left.37^{\circ} \mathrm{C}\right)$ at a ratio of $1: 10(\mathrm{v} / \mathrm{v})$ and $75 \mu \mathrm{l}$ immediately pipetted onto CometSlide $\mathrm{T}^{\mathrm{TM}}$. The slide was placed flat at $4{ }^{\circ} \mathrm{C}$ in a dark area of the refrigerator for 10 minutes. The slide was then immersed in prechilled lysis solution for 30-60 minute and in freshly prepared Alkaline Solution for another 20-60 minutes before transferring to a horizontal gel electrophoresis apparatus, facing the anode. The tank was then filled with alkaline solution until a level that covers the sample. Electrophoresis was carried out for $30 \mathrm{~min}$ at $25 \mathrm{~V}(300 \mathrm{~mA})$. Excess electrophoresis solution was removed by tapping the slides and were rinsed with $\mathrm{dH}^{2} \mathrm{O}$ and immersed again in $70 \%$ ethanol for $5 \mathrm{~min}$, air dried and finally stained with SYBR Green I.

\subsection{Determination of the hematological parameters}

Blood smears from each subject prepared by the hired medical technologist were analyzed at Paranaque Ultrasound Diagnostic Center Inc., Bacoor, Cavite, Philippines for the determination and measurement of the different haematological parameters. Nine blood parameters which include white blood cell (WBC), differential count with five WBC subtypes (neutrophils, eosinophils, monocytes, basophils and lymphocytes), total red blood cells (RBC) and the two red cell-related measures (haemoglobin \& hematocrit) were determined in this study.

\subsection{Comet capture and analysis}

Images of 100 randomly captured comets from each slide were examined at $200 \mathrm{X}$ magnification utilizing a fluorescence microscope equipped with a 
$530 \mathrm{~nm}$ excitation filter and a 590-nm barrier filter. The microscope was connected to a computer where the images can be seen. The acquired comet images were then saved in a compact disc. Comet Images analysis was performed using TriTek CometScore ${ }^{\mathrm{TM}}$ Freeware version 1.5 (Kumaravel and Jha, 2006). The software automatically calculated the DNA damage comet parameters shown to be good indicators of underlying damage: tail length and tail moment (Kumaravel and Jha, 2006).

Tail moment is measured in arbitrary units while tail length is measured in $\mu \mathrm{m}$. The tail length was calculated from the center of the nucleus/head to the leading edge of the tail while tail moment was calculated as the tail distance $\mathrm{x}$ ratio (i.e., sum of tail intensity/sum of cell intensity) (Olive et al., 1990).

\subsection{Statistical analysis}

Demographic data, comet parameters (tail length and tailmoment) and the measured values of the different hematological parameters (WBC, neutrophils, eosinophils, monocytes, basophils, lymphocytes, hemoglobin, hematocrit, Red Blood Cell Count) between the exposed and reference groups were statistically analyzed using the Student's two-tailed t test of IBM SPSS Statistics version 20.0. Relationship between length of exposure and age to DNA damage were also statistically analyzed using the Pearson correlation coefficient. The level of statistical significance was set at $\mathrm{p}<0.05$.

\section{Results}

Demographic characteristics of the studied population are presented in Table 1 . Student t-test of the respondent's ages and drinking habits (coffee drinkers, tea drinkers and alcohol drinkers) revealed a non-significant result. While, Student t-test and Chi-Squared test on marital status, smoking and reported recent illness between exposed and reference groups was significant.

Comet Assay yielded comets with varying degree of DNA damage measured through the global parameters, tail length (TL) and tail moment (TM) as presented in Table 2.

The mean tail length of the comets formed by the exposed group (Fig. 1) is almost doubled $(19.35 \pm 8.79 \mu \mathrm{m}$ vs. $8.48 \pm 3.41 \mu \mathrm{m})$, compared to the tail length of the reference subjects (Fig. 2). The mean tail moments of the exposed group (8.02 \pm 5.71 vs.1.93 \pm 1.43 ) is also four-fold higher compared to the reference group?

The possible effect of confounding factors on DNA damage like length of exposure, smoking habit, and drinking habit is also summarized in Table 2 and Table 3.

Student t-test of the tail lengths (Table 2) and tail moments (Table 3) of the length of exposure to fuel exhaust resulted to a statistically significant difference $(\mathrm{P}<0.05)$ between the groups compared.
Table 1: Demographic profile of the household helpers and housewives $(\mathrm{N}=50)$ and the urban female street sweepers $(\mathrm{N}=50)$ evaluated for DNA Damage

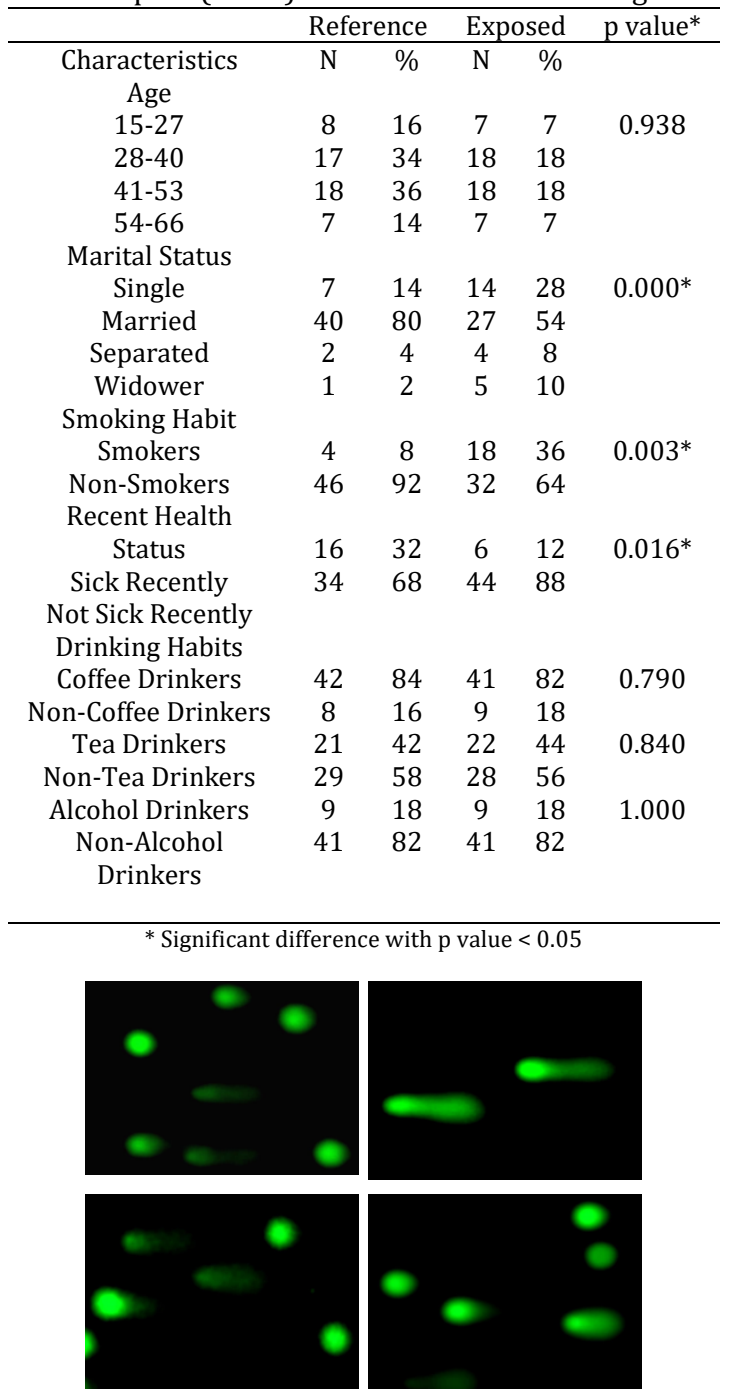

Fig. 1: Representative comet images of leucocytes from subjects of the reference group. Slides were stained with SYBR Green and analyzed using a fluorescence microscope (Magnification 200X)
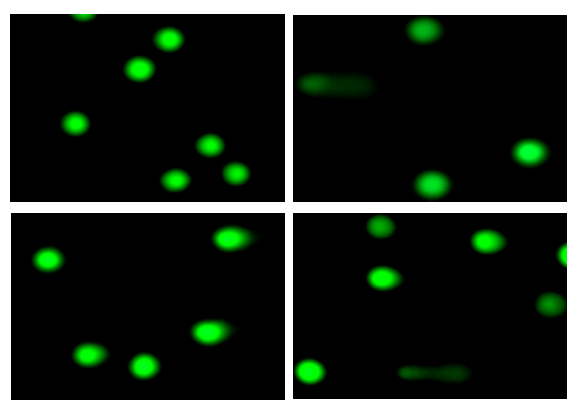

Fig. 2: Representative comet images of leucocytes from subjects of the reference group. Slides were stained with SYBR Green and analyzed using a fluorescence microscope (Magnification 200X).

There was also a significant increase in the mean of the tail lengths and tail moments in the smoking exposed subjects when compared to the smoking reference subjects. Similarly, coffee drinkers, tea drinkers and alcohol drinkers of the exposed group also recorded a significantly higher tail lengths and tail moments, thus higher DNA damage compared to reference subjects (Tables 2 and 3 ). 
Table 2: Effect of confounding factors on the mean tail length of the comets

\begin{tabular}{cccc}
\hline $\begin{array}{c}\text { Confounding } \\
\text { Factors }\end{array}$ & \multicolumn{3}{c}{ Tail length $(\mu \mathrm{m})$} \\
\hline Mean & Reference & Exposed & $\mathrm{p}$ value \\
\hline Length of Exposure & $4.68 \pm 3.41$ & $19.35 \pm 8.79$ & $0.00^{*}$ \\
Smokers & $4.66 \pm 3.32$ & $19.36 \pm 8.31$ & $0.00^{*}$ \\
Coffee Drinkers & $8.85 \pm 3.43$ & $18.36 \pm 8.31$ & $0.00^{*}$ \\
Tea Drinkers & $8.11 \pm 2.92$ & $22.02 \pm 8.72$ & $0.00^{*}$ \\
Alcohol Drinkers & $9.60 \pm 5.61$ & $22.24 \pm 8.69$ & $0.000^{*}$ \\
\hline \multicolumn{4}{c}{$*$ Significant difference with p value $<0.05$} \\
\end{tabular}

Table 3: Effect of confounding factors on the mean tail moment of the comets

\begin{tabular}{|c|c|c|c|}
\hline \multirow[t]{2}{*}{$\begin{array}{c}\text { Confounding } \\
\text { Factors } \\
\end{array}$} & \multicolumn{3}{|c|}{ Tail length $(\mu \mathrm{m})$} \\
\hline & Reference & Exposed & $\mathrm{p}$ value \\
\hline Mean & $1.93 \pm 1.43$ & $8.02 \pm 5.71$ & $0.00^{*}$ \\
\hline Length of Exposure & $1.04 \pm 1.31$ & $7.83 \pm 5.91$ & $0.00^{*}$ \\
\hline Smokers & $1.04 \pm 1.31$ & $7.83 \pm 5.91$ & $0.00 *$ \\
\hline Coffee Drinkers & $2.11 \pm 1.49$ & $7.33 \pm 5.57$ & $0.00^{*}$ \\
\hline Tea Drinkers & $1.99 \pm 1.38$ & $9.18 \pm 6.44$ & $0.00 *$ \\
\hline Alcohol Drinkers & $2.51 \pm 2.23$ & $9.53 \pm 6.52$ & $0.01 *$ \\
\hline
\end{tabular}

The measured values of the hematological parameters namely hemoglobin, hematocrit, red blood cell count, white blood cell count, segmenters and lymphocytes of the reference and exposed groups are summarized in Table 4. The Student t-test of the hematological parameters between exposed and reference groups did not differ significantly $(\mathrm{p}<$ 0.05).

\section{Discussion}

The results of the present study showed that occupational exposure to automobile exhaust can instigate and enhance DNA damage among urban female streetsweepers. Such DNA damage can be also enhanced by confounding factors like length of exposure, smoking and drinking of coffee, tea and alcohol. This result is in good agreement with earlier reports (Zhao et al., 1998; Heuser et al., 2002; Zhu et at., 2003; Müller et al., 2004; Knudsen et al. 2005; Singh et al., 2010; Prasad et al., 2013).

Table 4: Comparison of the effect of hematological parameters on DNA damage

\begin{tabular}{ccccc}
\hline Hematological Parameter & Reference & Exposed & $\mathrm{X}^{2}$ & $\mathrm{p}$ value \\
\hline Hemoglobin $(20-150 \mathrm{mg} / \mathrm{L}$ & $143.5 \pm 11.9$ & $144.8 \pm 12.7$ & -0.55 & 0.58 \\
Hematocrit & $0.44 \pm 0.03$ & $0.44 \pm 0.04$ & -0.36 & 0.72 \\
Red Blood Cell Count & $4.90 \pm 0.39$ & $4.91 \pm 0.42$ & -0.07 & 0.94 \\
White Blood Cell Count & $8.67 \pm 1.51$ & $8.60 \pm 1.83$ & 0.21 & 0.84 \\
Segmenters & $0.59 \pm 0.12$ & $0.57 \pm 0.14$ & 0.56 & 0.58 \\
Lymphocytes & $0.41 \pm 0.12$ & $0.42 \pm 0.14$ & 0.44 & 0.66 \\
\hline Values for hematological parameters are means \pm SD; ${ }^{*}$ Significant Difference with P Value $<0.05$
\end{tabular}

Fuel emissions have carcinogenic properties since they contain dangerous substances that are able to react with and change the genetic material, of the affected organisms. Substances that have mutagenic and carcinogenic effects are called genotoxicants.

Urban air pollutants contributed by vehicles contain DNA damaging components like PAH's and particulate matter (Faiz et al., 1996). To recall, the street sweepers who participated in this study are the ones working along Taft Avenue, Manila, where TSP and PM2.5 exceeds National Ambient Air Quality Guideline Value (NAAQGV) and WHO long term guideline value of $10 \mu \mathrm{g} / \mathrm{m} 3$ respectively based on the 2005-2011air quality monitoring (http://cleanairasia.org/portal/system/files/attach/ Philippines_Air_Quality_Profile_-_2010Edition). In the 2011 roadside monitoring in NCR, Taft Ave. catalogued the highest TSP level of $221 \mu \mathrm{g} / \mathrm{Ncm}$, doubly exceeding the long term guideline value of 90 $\mu \mathrm{g} / \mathrm{Ncm}$.

The DNA damage measured by the comet assay may reflect not only the actual levels of DNA damage due to current exposure indicative of recent pollution status but even past exposures to the DNA damaging substances (Kopjar et al., 2006; Deventer, 1996; Bonassi et al., 1995). The comet assay measures strand breaks resulting from the complex interaction of two main processes: actual and recent DNA damage (direct scission or alkali labile site and adduct) and repair activation or inhibition (Klobučar et al., 2003), thus the measured damage level is the result of equilibrium between damage infliction and repair. This study also affirms the higher sensitivity of the comet assay in quantitating even low levels of DNA damage (one break per 1010 Da of DNA) (Gedik et al., 1992) from directly formed strand breaks (SSB) and even strand breaks due to alkaline treatment (Møller et al., 2000) together with alkali labile sites (ALS) and DNA-DNA/DNA-protein crosslinking (Tice et al., 2000; Hartmann et al., 2003) in individual eukaryotic cells (Singh et al., 1988).

The DNA damage detected by the comet assay did not affect the mean values of WBC, segmenters/neutrophils, lymphocytes, hemoglobin, hematocrit, and Red Blood Cell Count. The insignificant effect of fuel exhaust exposure to the chosen hematological factors may indicate that the dose and duration of exposure to the genotoxicant is not that high to cause an effect on DNA damage. Length/duration of exposure was pointed out by Ajugwo et al. (2014) as the most probable factor that causes the reduction in RBC (Red blood cell count), WBC (White blood cell count), PCV (Packed cell volume), $\mathrm{Hb}$ (Haemoglobin concentration), MCV (Mean cell volume), MCH (Mean cell haemoglobin) and MCHC (Mean cell haemoglobin concentration) in fuel attendants and auto mechanics exposed to gasoline fumes.

\section{Conclusion}

Occupational exposure to fuel exhaust did cause a significant increase on the DNA damage level measured on lymphocytes with the comet assay. This 
study demonstrated the sensitivity of the comet test as a biomarker in analyzing DNA damage and repair.

\section{Acknowledgement}

The authors wish to thank the subjects who volunteered to participate. This research was financially supported by the Department of Science and Technology- Philippine Council for Advanced Science and Technology Research and Development.

\section{References}

Abbey DL, Hwang BL, Burchett RJ, Vancuren T, and Mills PK (1995). Estimated long-term ambient concentrations of PM10 and development of respiratory symptoms in a nonsmoking population. Archive for Environmental Health: An International Journal, 50(2): 139-152.

Abuzo AA (2005). Development of drive cycle and emission models for in-use tricycles in metro Manila. Ph.D. Dissertation, University of the Philippines Diliman, Quezon, Philippines.

Ajugwo A, Adias T, Aghatise K, Fadairo J, and Nyenke C (2014). Reduced haematological indices in auto-mechanics and fuel attendants in Elele Nigeria. American Journal of Medical and Biological Research, 2(1): 1-4.

Bonassi S, Bolognesi C, Abbondandolo A, Barale R, Bigatti P, Camurri L, Dalpra L, De Ferrari M, Forni A, and Lando C (1995). Influence of sex on cytogenetic end points-evidence from a large human sample and review of the literature. Cancer Epidemiology, Biomarkers and Prevention, 4(6): 671 679.

Carrano AV and Natarajan AT (1988). Considerations for population monitoring using cytogenetic techniques. Mutation Research/Genetic Toxicology, 204(3): 379-406.

Deventer K (1996). Detection of genotoxic effects on cells of liver and gills of B. rerio by means of single cell gel electrophoresis. Bulletin of Environmental Contamination and Toxicology, 56(6): 911-918.

ElAssouli SM, AlQahtani MH, and Milaat W (2007). Genotoxicity of air borne particulates assessed by comet and the Salmonella mutagenicity test in Jeddah, Saudi Arabia. International Journal of Environmental Research and Public Health, 4(3): 216-223.

Faiz A, Weaver CS, and Walsh MP (1996). Air pollution from motor vehicles: Standards and technologies for controlling emissions. World Bank Publications, Washington, USA.

Garshick E, Laden F, Hart J, Rosner B, Smith TJ, and Dockery DW (2004). Lung cancer in railroad workers exposed to diesel exhaust. Environmental Health Perspectives, 112(15): 15391543.

Gedik CM, Ewen SW, and Collins AR (1992). Single-cell gel electrophoresis applied to the analysis of UV-C damage and its repair in human cells. International Journal of Radiation Biology, 26(3): 313-320.

Goud KI, Shankarapppa K, Vijayashree B, Rao KP, and Ahuja YR (2001). DNA damage and repair studies in individuals working with photocopying machines. Indian Journal of Human Genetics, 1(2): 139-143.

Gustavsson P, Evanoff B, and Hogstedt C (1993). Increased risk of esophageal cancer among workers exposed to combustion products. Archives of Environmental Health: An International Journal, 48(4): 243-245.

Hansen AM, Wallin H, Binderup ML, Dybdahl M, Autrup H, Loft S, and Knudsen LE (2004). Urinary 1-hydroxypyrene and mutagenicity in bus drivers and mail carriers exposed to urban air pollution in Denmark. Mutation Research/Genetic Toxicology and Environmental Mutagenesis, 557(1): 7-17.
Hartmann A, Agurell E, Beevers C, Brendler-Schwaab S, Burlinson B, Clay P, Collins A, Smith A, Speit G, Thybaud V, and Tice R (2003). Recommendations for conducting the in vivo alkaline Comet assay. Mutagenesis, 18(1): 45-51.

Heuser VD, Da Silva J, Moriske HJ, Dias JF, and de Freitas TR (2002). Genotoxicity biomonitoring in regions exposed to vehicle emissions using the comet assay and the micronucleus test in native rodent Ctenomys minutus. Environmental and Molecular Mutagenesis, 40(4): 227-235.

Howard P and Christina P (2000). The Philippines Environment Monitor. World Bank Publications, Washington, USA.

IARC (1989). Monographs on the evaluation of the carcinogenic risks to humans, Occupational exposures in petroleum refining: Crude oil and major petroleum fuels. International Agency for Research in Cancer. Lyon, France. Available at: https://www.iarc.fr/

Jones AYM, Lam PKW, and Dean E (2006). Respiratory health of bus drivers in Hong Kong. International Archives of Occupational \& Environmental Health, 79(5): 414-418.

Kagawa J (2002). Health effects of diesel exhaust emissions-a mixture of air pollutants of worldwide concern. Toxicology, 181: 349-353.

Klobučar GIV, Pavlica M, Erben R, and Papeš D (2003). Application of the micronucleus and comet assays to mussel Dreissena polymorpha haemocytes for genotoxicity monitoring of freshwater environments. Aquatic Toxicology, 64(1): 15-23.

Knudsen LE, Gaskell M, Martin EA, Poole J, Scheepers PTJ, Jensen A, Autrup H, and Farmer PB (2005). Genotoxic damage in mine workers exposed to diesel exhaust, and the effects of glutathione transferase genotypes. Mutation Research-Genetic Toxicology and Enviornmental Mutagenesis, 583(2): 120-132.

Kopjar N, Zeljezic D, and Garaj-Vrhova V (2006). Evaluation of DNA damage in white blood cells of healthy human volunteers using the alkaline comet assay and the chromosome aberration test. Acta Biochimica Polonica-English Edition, 53(2): 321-336.

Krivoshto IN, Richards JR, Albertson TE, and Derlet RW (2008). The toxicity of diesel exhaust: Implications for primary care. The Journal of the America Board of Family Medicine, 21(1): 55-62.

Kumaravel TS and Jha AN (2006). Reliable comet assay measurements for detecting DNA damage induced by ionising radiation and chemicals. Mutation Research/Genetic Texicology and Environmental Mutagenesis, 605(1-2): 7-16.

Li N and Nel AE (2006). The cellular impacts of diesel exhaust particles: beyond inflammation and death. European Respiratory Journal, 27: 667-668.

Møller P, Knudsen LE, Loft S. and Wallin H (2000). The comet assay as a rapid test in biomonitoring occupational exposure to DNA-damaging agents and effect of confounding factors. Cancer Epidemiology and Prevention Biomarkers, 9(10): 1005-1015.

Müller A, Farombi E, Møller P, Autrup H, Vogel U, Wallin H, Dragsted L, Loft S, and Binderup M (2004). DNA damage in lung after oral exposure to diesel exhaust particles in Big Blue rats. Mutation Research/Fundamental and Molecular Mechanisms of Mutagenesis, 550(1): 123-132.

Netterstrom B (1988). Cancer incidence amongst urban bus drivers in Denmark. International Archives of Occupational and Environmental Health, 61(3): 217-221.

Olive PL, Banáth JP, and Durand RE (1990). Heterogeneity in radiation-induced DNA damage and repair in tumor and normal cells measured using the "comet" assay. Official Journal of the Radiation Research Society, 122(1): 86-94.

Pope CA, Thun MJ, Namboodiri MM, Dockery DW, Evans JS, Speizer FE, and Health Jr CW (1995). Particulate air pollution as a predictor of mortality in a prospective study of U.S. adults. 
American Journal of Respiratory and Critical Care Medicine, 151(3_PT_1): 669-674.

Prasad BS, Vidyullatha P, Venkata RP, Tirumala VG, Varre S, Penagaluru UR, Grover P, Mundluru HP, and Penagaluru PR (2013). Evaluation of oxidative stress and DNA damage in traffic policemen exposed to vehicle exhaust. Biomarkers. 18(5): 406-411.

Richman BT (1994). Air Pollution in the World's Megacities. Environment: Science and Policy for Sustainable Development, 36(2): 4-37.

Siemiatycki J, Gerin M, Stewart P, Nadon L, Dewar R, and Richardson L (1988). Associations between several sites of cancer and ten types of exhaust andcombustion products. Scandinavian Journal Work Environmental Health, 14(2): 7990.

Singh NP, McCoy MT, Tice RR, and Schneider EL (1988). A simple technique for quantitation of low levels of DNA damage in individual cells. Experimental Cell Research, 175(1): 184-191.

Singh RK, Mishra SK, Kumar N, and Singh AK (2010). Assessment of DNA damage by comet assay in lymphocytes of workers occupationally exposed to petroleum fumes. International Journal of Genetics, 2(1): 18-22.
Tice RR, Agurell E, Anderson D, Burlinson B, Hartmann A, Kobayashi H, Miyamae Y, Rojas E, Ryu JC, and Sasaki YF (2000). Single cell gel/comet assay: Guidelines for in vitro and in vivo genetic toxicology testing. Environmental Molecular Mutagen, 35(3): 206-221.

Tovalin H, Valverde M, Morandi MT, Blanco S, Whitehead L, and Rojas E (2006). DNA damage in outdoor workers occupationally exposed to environmental air pollutants. Occupational and Environmental Medicine, 63(4): 230-236.

Zhao X, Niu J, Wang Y, Yan C, Wang X, and Wang J (1998). Genotoxicity and chronic health effects of automobile exhaust: A study on the traffic policemen in the city of Lanzhou. Mutation Research/Genetic Texicology and Environmental Mutagenesis, 415(3): 185-190.

Zhou W, Yuan D, Ye S, Qi P, Fu C, and Christiani DC (2001). Health effects of occupational exposures to vehicle emissions in Shanghai. International Journal for Occupational and Environmental Health, 7(1): 23-30.

Zhu CQ, Lam T, Jiang CQ, Wei BX, Chen YH, and Xu QR (2003). A study on lymphocyte DNA damage in traffic policemen in Guangzhou. Zhonghua Lao dong Wei sheng Zhi ye bing Za zhi [Chinese Journal of Industrial Hygiene and Occupational Disease], 21(1): 41-44. 